\title{
The Development of a Current Attitude Scale Towards Geometry
}

\author{
Meral CANSIZ AKTAŞ ${ }^{1, *}$ \& Devrim Yaşar AKTAŞ ${ }^{2}$ \\ ${ }^{1}$ Ordu University, Ordu, TURKEY; ${ }^{2}$ Fatih Anatolian High School, Ordu, \\ TURKEY
}

Abstract - The aim of this study is to develop a current, valid and reliable geometry attitude scale which can be used to identify high school students' attitudes towards geometry. The study was carried out in five stages that are: (1) Item collection for draft scale and detection of content validity, (2) Practicing, (3) Analyzing the obtained data (item analysis and factor analysis (detection of construct validity)), (4) Calculating reliability and (5) constructing the final form of the scale. The draft scale consisting of 40 items was administered to 639 high school students at 5 different types of high school in Ordu. As a result of the analysis procedures, the geometry scale grouped into four factors accounted for $47.03 \%$ of total variance with 24 items and Cronbach- Alpha, total internal reliability coefficient, of the final scale was calculated as 0.895 . It is thought that the attitude scale developed for this research fills gap as it takes the new objective, skills and approaches introduced by the curriculum changes in our country into account, and there is not any current scale developed in this direction.

Key words: geometry attitude scale, study of validity and reliability

DOI No: http://dx.doi.org/10.12973/nefmed208

\section{Summary}

Introduction: Geometry takes place in the curriculum starting with elementary education due to its benefits for students' critical thinking and problem solving abilities and thanks to its contribution to the teaching of other subjects in mathematics. As well as being an important part of mathematics used in real life, geometry is also being used in science and art (Baykul, 2002). However, numerous studies show that students encounter a lot of difficulties while learning geometry (Ubuz \& Üstün, 2003; Üstün, 2003). The findings of the Third International Mathematics and Science Study show that Turkish students got the lowest mean

*Corresponding author: Meral CANSIZ AKTAŞ, Assist. Prof. Dr., Department of Elementary Education, Faculty of Education, Ordu University, Ordu, TURKEY.

E-mail: cansizmeral@hotmail.com 
scores from the geometry part of the test. Of the 38 participating countries, Turkey was among the least successful participants as for geometry results. (Mullis et al., 2000). On the other hand, attitudes play a significant role in the achievement of learners (Aşkar, 1986; Hammouri, 2004; Işı1k \& Çağdaşer, 2009; Ma \& Xu, 2004; National Council of Teachers of Mathematics [NCTM], 2000; Papanastasiou, 2000; Papanastasiou, 2002; Peker \& Mirasyedioğlu, 2003; Savaş, Taş \& Duru, 2010; Webster \& Fisher, 2000; Wilkins \& Ma, 2003; Y1ld1z, 2006). Therefore, the aim of this study is to develop a "valid and reliable geometry attitude scale" which can be used to identify high school students' attitudes towards geometry.

Methodology: The draft scale consisting of 40 items was administered to 639 (302 girls and 337 boys) high school students at five different types of high schools in Ordu city. While developing attitude scale, the process included five following phases: (1) Item collection for draft scale and detection of content validity, (2) Practicing, (3) Analyzing the obtained data (item analysis and factor analysis (detection of construct validity)), (4) Calculating reliability and (5) constructing the final form of the scale.

In the process of item collection for draft scale and detection of content validity, previously developed attitude scales about mathematics and geometry (Aşkar, 1986; BarutçuAkyar, 2010; Bayram, 2004; Bindak, 2004; Duatepe \& Ubuz, 2007; Güven, 2006; MEB, 2004; MEB, 2005a; MEB, 2005b; Nazlıçiçek \& Erktin, 2002; Ocak \& Dönmez, 2010; Sulak, 2002; Tutak, 2008; Üzel, 2007) and also 2010 geometry high school curriculum (MEB, 2010) were examined. The initial scale consisting of 40 items was examined by two academicians from 19 Mayıs University who study developing attitude scales and by four doctoral students who are studying on developing attitude scales. SPSS 16.0 statistical program was used to perform exploratory analysis, and LISREL 8.54 was used to perform confirmatory analysis.

Results: In item analysis of mean differences between upper and lower groups stage, independent sample $t$ test was used to find out if there was a significant difference between mean scores of two (upper and lower) groups of $27 \%$. Consequently, it was seen that all of the items had significant $\mathrm{t}$ values so no items removed. On the other hand, correlations between item scores and scale scores were calculated and 12 items $(2,4,5,8,11,18,20,24,25,34,36$ and 39) were removed because of having item-scale correlations less than 0.4. The itemscale correlations of other items changed between .405-.671 and calculated values of t were significant. It showed that these items had a quality of discriminating people from each other. 
On the other hand, exploratory factor analysis and confirmatory factor analysis were performed in order to examine the construct validity. Before factor analysis, the adequacy of data for factor analysis was examined and KMO coefficient was found to be 0.942 . In order to examine factor structure of the scale, exploratory factor analysis was performed by using principal component analysis with varimax rotation. Since it was difficult to describe the factor structure of the attitude scale according to the initial factor analysis, a second factor analysis was performed with the data after removing item 3, item 6 and item 37 (subtraction of loadings less than 0.1 ). Furthermore, the third factor analysis was performed with the data after removing item 10 because of the same reason.

As a result of these steps, the following rotated component matrix table was formed.

Table 1 Items' factor loading and communalities values.

\begin{tabular}{|c|c|c|c|c|c|c|}
\hline \multirow[b]{2}{*}{ Item number } & \multirow[b]{2}{*}{ Communalities } & \multirow{2}{*}{$\begin{array}{c}\text { Factor }-1 \\
\text { loading } \\
\text { value }\end{array}$} & \multicolumn{4}{|c|}{ Rotated factor loading value } \\
\hline & & & Factor-1 & Factor-2 & Factor-3 & Factor-4 \\
\hline Item 35 & .574 & .612 & .709 & & & \\
\hline Item 19 & .560 & .614 & .701 & & & \\
\hline Item 23 & .489 & .566 & .634 & & & \\
\hline Item 21 & .489 & .649 & .573 & & & \\
\hline Item 1 & .421 & .576 & .568 & & & \\
\hline Item 31 & .400 & .578 & .549 & & & \\
\hline Item 33 & .475 & .580 & .514 & & & .404 \\
\hline Item 28 & .474 & .543 & & .619 & & \\
\hline Item 32 & .452 & .574 & & .603 & & \\
\hline Item 26 & .435 & .553 & & .574 & & \\
\hline Item 40 & .475 & .519 & & .536 & & \\
\hline Item 22 & .472 & .543 & & .524 & & \\
\hline Item 12 & .373 & .439 & & .513 & & \\
\hline Item 38 & .479 & .555 & & .509 & .383 & \\
\hline Item 30 & .441 & .613 & .335 & .438 & & \\
\hline Item 17 & .554 & .502 & & & .698 & \\
\hline Item 27 & .496 & .524 & & & .664 & \\
\hline Item 13 & .422 & .479 & & & .604 & \\
\hline Item 9 & .475 & .512 & & .326 & .581 & \\
\hline Item 15 & .354 & .428 & & & .524 & \\
\hline Item 7 & .428 & .505 & & & .515 & \\
\hline Item 16 & .475 & .529 & & & .471 & .348 \\
\hline Item 14 & .616 & .479 & & & & .743 \\
\hline Item 29 & .589 & .541 & & & & .669 \\
\hline
\end{tabular}

As it is seen on the Table 1, analysis revealed that the scale was a four-factor scale. The total variance explained by these four factors were found to be $47.03 \%$. Factor 1 explained $14.69 \%$ of the variance, factor 2 explained $12.48 \%$ of the variance, factor 3 explained $12.31 \%$ 
of the variance and factor 4 explained $7.54 \%$ of the variance. By examining the items under these factors, first factor (including items 1, 19, 21, 23, 30, 31, 35) was named as "selfefficacy beliefs and enjoying geometry", second factor (including items 12, 22, 26, 28, 32, 40) was named as "connecting geometric concepts", third factor (including items 7, 9, 13, 15, $16,17,27,38$ ) was named as "connecting geometry to real life" and the last factor (including items 14, 29, 33) was named as "situation of geometry lesson in curriculum". A confirmatory factor analysis was also run to test the validity of four-factor structure in the scale. The results of first order confirmatory factor analysis $\left(\chi^{2}(246, N=639)=640.50, p<.001\right.$, RMSEA $=$ $.05, \mathrm{CFI}=.97)$ and second order confirmatory factor analysis $\chi^{2}(248, N=639)=638.56, p<$ .001 , RMSEA $=.05, \mathrm{CFI}=.97)$ indicated that the model was well fit. On the other hand, Cronbach-Alpha value was calculated as 0.895 and for each factor it was found as 0.810 , $0.717,0.780$ and 0.614 .

Conclusions and Suggestions: Although the statement "to be able to develop positive attitude towards geometry" among the purposes of 2010 geometry curriculum, there is not a proposed geometry attitude scale in the curriculum for teachers to use in their applications. In this study, a valid and reliable attitude scale was developed by taking into consideration the components' of the 2010 geometry curriculum. In this regard, it is thought and recommended that the scale can be used to determine students' attitudes towards geometry and the conclusions can be drawn according to some variables (gender, school type, student's level in mathematics, student's level in geometry etc.). Moreover, it can be used at different times and it is appropriate for defining students' attitudes towards geometry in the implementing process of new geometry curriculum. 


\title{
Geometriye Yönelik Güncel Bir Tutum Ölçeğinin Geliştirilmesi
}

\author{
Meral CANSIZ AKTAŞ ${ }^{1,+}$, Devrim Yaşar AKTAŞ ${ }^{2}$ \\ ${ }^{1}$ Ordu Üniversitesi, Ordu, TÜRKİYE; ${ }^{2}$ Fatih Anadolu Lisesi, Ordu, TÜRKİYE
} Makale Gönderme Tarihi: 27.06.2011

Makale Kabul Tarihi: 04.07.2013

Özet - Bu araştırmanın amacı, lise öğrencilerinin geometri dersine yönelik tutumlarını belirlemede kullanılabilecek geçerli ve güvenilir bir ölçek geliştirmektir. Araştırma beş aşamadan oluşacak şekilde yürütülmüştür: (1) Madde havuzunun oluşturulması ve kapsam geçerliliğinin sağlanması, (2) Uygulama, (3) Elde edilen verilerin analizi (madde analizi ve faktör analizi (yapı geçerliliğinin sağlanması)), (4) Güvenirlik hesabı, (5) Ölçeğin son şeklinin verilmesi. 40 maddeden oluşan taslak ölçek Ordu ilinde farklı tipteki okullarda öğrenim görmekte olan 639 lise öğrencisine uygulanmıştır. Yapılan analizler sonucu 24 maddeden oluşan nihai ölçeğin dört alt faktörden oluştuğu, açıklanan toplam varyansın \%47.03 olduğu belirlenmiş ve Cronbach-Alfa güvenirlik katsayısı 0.895 olarak hesaplanmıştır. Araştırmada geliştirilen tutum ölçeğinin, ülkemizde öğretim programı değişikliğinin beraberinde getirdiği yeni amaç, beceri ve yaklaşımları hesaba katması ve bu doğrultuda geliştirilmiş olan herhangi bir güncel ölçeğe rastlanmamış olması nedeniyle bu alandaki boşluğu doldurduğu düşünülmektedir.

Anahtar kelimeler: geometri tutum ölçeği, geçerlilik- güvenirlik çalışması

\section{Giriş}

Geometri öğrencilerin eleştirel düşünme ve problem çözme becerilerine katkıda bulunması, matematiğin diğer konularının öğretiminde yardımcı olması, matematiğin günlük yaşamda kullanılan önemli bir kısmı olması, bilim ve sanatta kullanılması, yaşadıkları dünyanın öğrenciler tarafından yakından tanınmasına ve değerinin anlaşılmasına yardımcı olması nedeniyle ilköğretimden itibaren öğretim programları içerisinde yer almaktadır (Baykul, 2002). Ancak yapılan çalışmalar öğrencilerin geometride pek çok zorluklarla karşılaştıklarını göstermektedir (Ubuz \& Üstün, 2003; Üstün, 2003). Zira Üçüncü Ulusal Matematik ve Fen Çalışmasında (TIMSS) beş matematik alanı kapsamında değerlendirilen

\footnotetext{
† İletişim: Meral CANSIZ AKTAŞ, Yrd. Doç. Dr., İlköğretim Bölümü, Eğitim Fakültesi, Ordu Üniversitesi, Ordu, TÜRKIYE.

E-posta: cansizmeral@hotmail.com
} 
Türk öğrencileri en düşük puanı geometri alanından almışlar ve otuz sekiz ülke arasından sondan beşinci sırada yer almışlardır (Mullis ve diğer., 2000).

Tutum, sonradan kazanılan, yaşantılar yoluyla öğrenilen, belirli süre devam eden, doğrudan gözlenemeyen ve olumlu ya da olumsuz davranışlara yol açabilen psikolojik bir süreçtir (Tavşancıl, 2005). Bilindiği gibi tutumlar başarıyı etkilemekte (Aşkar, 1986; Işık \& Çağdaşer, 2009; Hammouri, 2004; Ma \& Xu, 2004; NCTM, 2000; Papanastasiou, 2000; Papanastasiou, 2002; Peker \& Mirasyedioğlu, 2003; Savaş, Taş \& Duru, 2010; Webster \& Fisher, 2000; Wilkins \& Ma, 2003; Yıldız, 2006) ve öğrencilerin belli derslerdeki tutumlarına odaklanan çalışmalar önem kazanmaktadır (Duatepe \& Çilesiz, 1999). Öğrencilerin geometri dersinde başarılı olmaları için öncelikle bu derse yönelik olumlu tutum içinde bulunmaları gerekir. Geometriye yönelik tutumları bilinmeden bunu yapmanın mümkün olmayacağı gerçeği göz önünde bulundurulursa geçerli ve güvenilir bir tutum ölçeğine olan ihtiyaç ortaya çıkmaktadır (Bindak, 2004).

Ülkemizde 1992 yılından itibaren okutulmakta olan matematik öğretim programlarında (MEB, 1992; MEB, 2005a; MEB, 2005b) matematik dersinin genel hedefleri içerisinde matematiğe yönelik olumlu tutum geliştirebilme yer almaktadır. Yine 2009-2010 eğitimöğretim yılı itibarıyla uygulamaya konan geometri yeni öğretim programında geometri dersinin amaçları arasında da "geometriye yönelik olumlu tutum geliştirmek" (MEB, 2010, s. 7) bulunmaktadır. Literatür incelendiğinde matematik dersine yönelik tutumları belirleme amacıyla geliştirilen birçok ölçek olmasına rağmen geometri dersine yönelik tutumları belirlemek amacıyla kullanılabilecek ölçeklerin daha az sayıda olduğu dikkat çekmektedir (Bkz. Tablo 2). Diğer taraftan ilgili yazarın tez çalışmasının bir kısmında, tezde ele alınan uygulamanın öğrencilerin geometriye yönelik tutumlarını nasıl etkilediğini belirlemek amacıyla kullanılan ölçeklere de rastlanmıştır (Barutçu-Akyar, 2010; Bayram, 2004; Güven, 2006; Tutak, 2008). Bu ölçeklerden yalnızca ikisinin (Bindak, 2004; Barutçu-Akyar, 2010) ortaöğretim öğrencilerinin geometriye yönelik tutumlarını belirlemek için kullanıldı̆̆ çalışmaların daha önce uygulamada olan geometri öğretim programı kapsamında yürütüldüğü belirlenmiştir. $\mathrm{Bu}$ durum, yeni geometri öğretim programı ile birlikte değişen amaçlar, beceriler (temel beceriler, öz düzenleme becerileri, duyuşsal özellikler, psikomotor beceriler) ve yaklaşımları (Bkz. MEB, 2010, s. 8-19) hesaba katarak geliştirilecek bir ölçeğe ihtiyaç olduğunu göstermektedir. Diğer taraftan 2010 Geometri Dersi Öğretim Programında (MEB, 2010) "geometriye yönelik olumlu tutum geliştirmek" dersin amaçları arasında olmasına rağmen örnek tutum ölçeğine yer verilmemiştir. Bu durum çalışmanın önemini ve dolduracağı 
boşluğu bir kez daha ortaya koymaktadır. O halde yeni geometri öğretim programının uygulamaları esnasında öğrencilerin geometriye yönelik tutumlarını belirlemek için kullanılabilecek, tutum ölçeği geliştirme basamaklarını dikkate alarak tasarlanan geçerli ve güvenilir ölçeklere ihtiyaç duyulmaktadır. Bu anlamda araştırmanın amacı, lise öğrencilerinin geometri dersine yönelik tutumlarını belirlemede kullanılabilecek geçerli ve güvenilir güncel bir ölçek geliştirmektir.

Tablo 2 Literatürde Yer Alan İlgili Çalışmalar

\begin{tabular}{|c|c|c|c|c|c|c|c|c|}
\hline \multirow[t]{3}{*}{ Araştırmacı (lar) } & \multirow{2}{*}{\multicolumn{2}{|c|}{ Örneklem }} & \multicolumn{6}{|c|}{ Kullanılan Ölçek ile ilgili Bilgiler } \\
\hline & & & \multirow{2}{*}{$\frac{\bar{\Xi}}{\gtrless}$} & \multirow{2}{*}{ 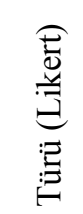 } & \multicolumn{2}{|c|}{$\begin{array}{c}\text { Madde } \\
\text { say1s1 }\end{array}$} & \multirow{2}{*}{ 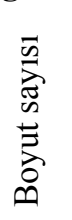 } & \multirow{2}{*}{ 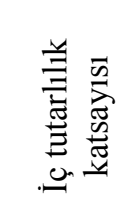 } \\
\hline & $\underset{\substack{n \\
\sum_{n}^{n}}}{\bar{n}}$ & 㲵 & & & 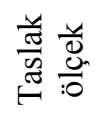 & 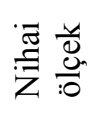 & & \\
\hline Aşkar (1986) & 240 & $\mathrm{~L}^{*}$ & $\mathrm{M}^{*}$ & 5'li & 44 & 20 & 1 & $\alpha=.96$ \\
\hline Erol (1989; akt. Nazlıçiçek \& Erktin, 2002) & 150 & $\mathrm{O}^{*}$ & $\mathrm{M}^{*}$ & 4’lü & $\mathrm{BY}^{*}$ & 70 & 6 & KR-20 $=.93$ \\
\hline Baykul (1990; akt. Övez, 2007) & 1056 & $\dot{\mathrm{I}}^{*}, \mathrm{O}^{*}$ & $\mathrm{M}^{*}$ & 5'li & $\mathrm{BY}^{*}$ & 30 & 1 & $\alpha=.96$ \\
\hline Aydınlı (1997; akt. Y1ldız \& Turanlı 2010) & $\mathrm{BY}^{*}$ & $\mathrm{BY}^{*}$ & $\mathrm{M}^{*}$ & 5 'li & $\mathrm{BY}^{*}$ & 60 & 3 & $\alpha=.97$ \\
\hline Duatepe \& Çilesiz (1999) & 230 & $\mathrm{~L}^{*}$ & $M^{*}$ & 5 'li & 44 & 38 & 4 & $\alpha=.96$ \\
\hline Nazliçiçek \& Erktin (2002) & 378 & $\dot{\mathrm{I}}^{*}$ & $M^{*}$ & 5 'li & 25 & 20 & 4 & $\alpha=.84$ \\
\hline Sulak (2002) & 25 & $\dot{\mathrm{I}}^{*}$ & $M^{*}$ & 5 'li & 18 & 16 & - & $\alpha=.78$ \\
\hline Ural (2007) & 117 & $\mathrm{O}^{*}$ & M & 5'li & 12 & 12 & 3 & $\alpha=.86$ \\
\hline Üzel (2007) & 120 & $\dot{\mathrm{I}}^{*}$ & $\mathrm{M}^{*}$ & 5 'li & 42 & 26 & - & $\alpha=, 88$ \\
\hline Özdoğan (2008) & 100 & $\dot{\mathrm{I}}^{*}$ & $\mathrm{M}^{*}$ & 5 'li & 32 & - & - & $\alpha=.82$ \\
\hline Ocak \& Dönmez (2010) & 200 & $\dot{\mathrm{I}}^{*}$ & $\mathrm{M}^{*}$ & 5'li & 40 & 19 & 3 & $\alpha=.91$ \\
\hline $\begin{array}{l}\text { Bulut, Ekici, İşeri \& Helvacı (2002; akt. } \\
\text { Bayram, 2004) }\end{array}$ & $\mathrm{BY}^{*}$ & $\mathrm{BY}^{*}$ & $\mathrm{G}^{*}$ & $\mathrm{BY}^{*}$ & $\mathrm{BY}^{*}$ & 17 & $\mathrm{BY}^{*}$ & $\alpha=.92$ \\
\hline Bayram (2004) & 90 & $\dot{\mathrm{I}}^{*}$ & $\mathrm{G}^{*}$ & 5 'li & 29 & 25 & 3 & $\alpha=.89$ \\
\hline Bindak (2004) & 131 & $\mathrm{O}^{*}$ & $\mathrm{G}^{*}$ & 5 'li & 46 & 25 & 4 & $\alpha=.94$ \\
\hline Güven (2006) & 25 & $\dot{\mathrm{I}}^{*}$ & $\mathrm{G}^{*}$ & 5 'li & 15 & 15 & - & $\alpha=.93$ \\
\hline Duatepe \& Ubuz (2007) & 332 & $\dot{\mathrm{I}}^{*}$ & $\mathrm{G}^{*}$ & 5'li & 17 & 12 & 2 & $\alpha=.93$ \\
\hline Tutak (2008) & 220 & $\dot{\mathrm{I}}^{*}$ & $\mathrm{G}^{*}$ & 3'lü & 29 & 20 & 1 & $\alpha=.86$ \\
\hline Barutçu-Akyar (2010) & 100 & $\mathrm{O}^{*}$ & $\mathrm{G}^{*}$ & 5 'li & 46 & 32 & 6 & $\alpha=.85$ \\
\hline
\end{tabular}

* İ: İlköğretim; O: Ortaöğretim; L: Lisans; M: Matematik; G: Geometri; BY: Bilgi yok 


\section{Yöntem}

Tarama araştırmaları, katılımcıların bir konu ile ilgili görüş, ilgi, beceri, yetenek, tutum vb. özelliklerini belirlendiği genellikle diğer araştırma desenlerine göre daha geniş örneklemler üzerinde yapılan çalışmalardır (Fraenkel \& Wallen, 2006). Tutumlar üzerine yapılan çalışmalarda geniş örneklemlere ulaşılması gerektiğinden tarama yöntemi bu tür çalışmalarda kullanılabilecek ideal bir yöntemdir.

\section{Evren ve Örneklem}

Çalışmanın evrenini Ordu ilinde geometri dersi okuyan öğrenciler oluşturmaktadır. Çalışmanın örneklemini ise farklı tip okullarda öğrenim görmekte olan toplam 302 kız ve 337 erkek öğrenci oluşturmaktadır. Örneklem seçiminde farklı türdeki okullara (Genel Lise, Anadolu Lisesi, Anadolu Öğretmen Lisesi, Meslek Lisesi) yer verilmesine önem verilmiştir. Örneklemde 48 Genel Lise, 305 Anadolu Lisesi, 100 Anadolu Öğretmen Lisesi, 75 Meslek Lisesi ve 111 Anadolu Teknik ve Endüstri Meslek Lisesi öğrencisi yer almaktadır. Geliştirilen taslak ölçek belirlenen okullarda 9. sınıftan 201 (77 kız ve 124 erkek), 10. Sınıftan 137 (76 kız ve 66 erkek), 11. Sınıftan 178 ( 81 kız ve 97 erkek) ve 12. Sınıftan 123 öğrenciye (66 kız ve 55 erkek) uygulanmıştır.

\section{Geometri tutum ölçeğinin geliştirilmesi aşamaları}

1. Madde havuzunun oluşturulması ve kapsam geçerliliğinin sağlanması

2. Uygulama aşaması

3. Madde analizi ve yapı geçerliliğini sağlama (faktör analizi) aşaması

i) Madde analizi

- Alt-Üst grup ortalamaları farkına dayalı madde analizi

- Korelasyona dayalı madde analizi

ii) Faktör analizi

- Açımlayıcı faktör analizi (AÇA)

- Doğrulayıcı faktör analizi (DFA)

4. Güvenirlik (Cronbach Alfa katsayısının) hesabı

5. Ölçeğin son şeklinin verilmesi

\section{Madde havuzunun oluşturulması ve kapsam geçerliliğinin sağlanması}

Taslak ölçeğe alınacak maddelere karar verme aşamasında daha önceden yapılmış çalışmalar kapsamında geliştirilen ölçekler (Tablo 2) ile uygulamada olan matematik öğretim 
programlarında (MEB, 2005a; MEB, 2005b) verilmiş olan tutum ölçekleri incelenmiştir. Ayrıca Geometri Öğretim Programı (MEB, 2010) gözden geçirilerek, giriş kısmında yer verilen özellikle duyuşsal boyut ile ilgili açıklamalar ön planda tutulmuştur. Burada öğrencilerin duyuşsal gelişiminin geometri kavram ve becerilerin geliştirilmesi sürecinde dikkate alınması gerektiği belirtilmiş, öğrencilere kazandırılması hedeflenen 19 duyuşsal özellik sıralanmıştır. Bu özellikler arasında verilen örneğin "Geometri ile ilgili konuları tartışır” (MEB, 2010, s.18) ifadesi ölçekte yer alan Madde 32'yi, “Gerçek hayatta geometrinin öneminin farkında olur" (MEB, 2010, s.19) ifadesi Madde 7, Madde 9, Madde 13, Madde 16, Madde 17 ve Madde 27'yi oluştururken kullanılmıştır. Benzer olarak "Geometri dersinde yapılması gerekenler dışında da çalışmalar yapar” (MEB, 2010, s.19) ifadesinden Madde 20, Madde 37 ve Madde 39; “Geometri ile ilgili olumlu tutumunu ve başarısını etkileyecek kaygılara kapılmaz” (MEB, 2010, s.18) ifadesinden Madde1, Madde 19, Madde 21, Madde 23, Madde 30, Madde 31 ve Madde 35 oluşturulurken yararlanılmıştır. Diğer taraftan kapsam geçerliliğini sağlamak için uzman görüşüne başvurulmuştur. Bunun için bu alanda çalışmaları olan 19 Mayıs Üniversitesi Eğitim fakültesinde görevli iki akademisyen ile yine aynı üniversitede tutum ölçeği geliştirme konusunda lisansüstü ders alan 4 kişinin görüşleri doğrultusunda taslak ölçekte yer alacak maddelere son şekli verilmiştir. $\mathrm{Bu}$ süreçte, olumlu tutum belirten maddeler ile olumsuz tutum belirten maddelerin sayıca eşit olmasına özen gösterilmiş, böylelikte taslak ölçekte 20 olumlu, 20 olumsuz madde yer almıştır. Bu maddeler, uygulanan kişilerin basmakalıp cevaplar vermesine önlem almak amacıyla rastgele bir sırada yazılmıştır.

Oluşturulan taslak ölçekte ayrıca uygulanan kişilerin demografik özellikleri hakkında bilgi edinmeye yönelik 4 tane kapalı uçlu (cinsiyet, okul türü, sınıf, bölüm) soru yer almaktadır. Tutumları ölçmeye yönelik olarak ankette yer verilen 40 soru ise "hiç katılmıyorum", "katılmıyorum", "kararsızım", "katılıyorum", “tamamen kat1liyorum" düzeyleri kullanılarak ifade edilmiştir.

\section{Uygulama Aşaması}

Uzman görüşleri alınarak son şekli verilen ölçek Ordu ilinde çeşitli okul tiplerinde öğrenim görmekte olan 652 öğrenciye uygulanmıştır. Verilerin analizi esnasında, kağıdın arka yüzünde yer alan soruları cevaplamadığı tespit edilen 5, basmakalıp cevaplar verildiği anlaşılan (örneğin hep aynı seçeneği işaretleyen) 8 ölçek değerlendirmeye alınmamıştır. Böylece madde analizi için değerlendirilen ölçek sayısı 639 olmuştur. 


\section{Madde Analizi ve Yapı Geçerliliğini Să̆lama (Faktör Analizi) Aşaması}

Araştırmada elde edilen verilerin analizi için önce iki aşamalı olarak yürütülen madde analizi arkasından faktör analizi (açımlayıcı faktör analizi ve doğrulayıcı faktör analizi) yapılmıştır. Madde analizi ve açımlayıcı faktör analizi için SPSS 16.0, doğrulayıcı faktör analizi için LISREL 8.54 programı kullanılmıştır.

\section{Madde Analizi}

Taslak ölçekte yer alan tutum maddelerinin, ölçülmek istenen tutumla ilişkisinin sınanması ve söz konusu tutumla ilgili farklı dereceleri ortaya koyma özellikleri bakımından incelenmesi madde analizi ile yapılmaktadır. Böylelikle tutum ile güçlü ve ayırt edici ilişkisi olan maddeler nihai ölçeğe alınmak üzere seçilir (Tezbaşaran, 1997). Her maddenin ölçme gücünü belirlemek için genel olarak iç tutarlık ölçütüne dayalı analiz ile korelasyona dayalı analiz olmak üzere iki farklı madde analizi önerilmektedir (Bindak, 2004). Bu çalışmada da alt-üst grup ortalamaları farkına ve korelasyona dayalı madde analizi yapılmıştır.

\section{Alt-Üst Grup Ortalamaları Farkına Dayalı Madde Analizi}

Ölçek geliştirme çalışmalarında \%27'lik alt ve üst grupların madde puanlarının bağımsız gruplar için t testi kullanılarak analiz edilmesi yoluyla yapılan bu analizde iç tutarlılık gruplar arasında gözlenen farkların anlamlılığı test edilerek sınanmakta, çıkan anlamlı fark testin iç tutarlılığını gösteren bir unsur olarak alınabilmektedir (Tavşancıl, 2005). Araştırmada öncelikle alt ve üst gruplara dayalı madde analizi yapılmıştır. Bu aşamada uygulamaya katılan her öğrencinin ölçek puanı hesaplanmıştır. Kişinin ölçekte yer alan maddelere verdiği puanların toplamı alınarak yapılan bu işlemde, olumsuz maddeler için yeniden kodlama yapılmıştır. Bu nedenle yüksek ölçek puanları olumlu tutum göstermektedir. Tüm bunlar dikkate alındığında taslak ölçekten elde edilebilecek en yüksek puan 200, en düşük puan 40'dır. Her bir öğrenci için bu yol ile elde edilen ölçek puanları, yüksek puandan düşük puana doğru sıralanmıştır. Bunun yapılmasında amaç, madde analizi için alt ve üst grupları oluşturmaktır. Daha sonra alttan ve üsten \%27’lik dilimde yer alan puanlar bırakılarak bunlar için bağımsız gruplar için $t$ testi yapılmıştır.

\section{Korelasyona Dayalı Madde Analizi}

$\mathrm{Bu}$ analizde her maddenin sahip olduğu puan dizisi ile ölçeğe ait puan dizisi arasındaki korelasyon hesaplanır. Burada ölçek puanı hesaplanırken söz konusu maddenin puanları hariç tutularak hesaplama yapılmalıdır (Tezbaşaran, 1997). Madde-toplam korelasyonu katsayıları için $r \geq 0.40$ için çok iyi bir madde, $0.30 \leq r \leq 0.39$ için iyi derecede bir madde, $0.20 \leq$ 
r $\leq 0.29$ için zorunlu görülmesi durumunda veya düzeltildikten sonra teste alınabilecek bir madde, $\quad r \leq 0.19$ için ise teste alınmaması gereken madde olarak yorumlanabileceği belirtilmektedir (Büyüköztürk, 2011; Kalayc1, 2005). Bu çalışmada da ölçeği oluşturan maddelerin madde-toplam korelasyonları hesaplanmış ve bu işlem sonucunda korelasyon değeri .40’’n altında olan maddeler ölçekten çıkarılmıştır.

\section{Faktör Analizi}

Açımlayıcı faktör analizinde faktörleştirme yöntemi olarak temel bileşenler analizi kullanılmıştır. Diğer taraftan dik döndürme yöntemlerinden maksimum değişkenlik (varimax) tekniği, yorumlamada açıklık ve anlamlılık sağlamak amacıyla işe koşulmuştur. Ölçeğin yapısı ise doğrulayıcı faktör analizi ile de sınanmıştır. Araştırmada önerilen modelin eldeki veriye uygun olup olmadığını değerlendirmek için en fazla benzerlik gösteren kestirim (maximum likelihood estimation) tekniği ve kovaryans matrisi kullanılmıştır. Modelin uyumuyla ilgili olarak, $\chi^{2}$ (Ki-Kare) testinin örneklem büyüklüğüne duyarlı olması nedeniyle $\mathrm{sd} / \chi^{2}$ oranı ölçütü dikkate alınmış, 1/5'in altındaki oran, iyi uyum olarak değerlendirilmiştir. Ayrıca CFI'nın .90 ve üzeri olması ve RMSEA'nın .06 ve altında olması önerilen model ile verinin iyi uyum gösterdiği yönünde değerlendirilmiştir (Byrne, 2001).

\section{Güvenirlik Hesabı}

Cevaplayıcının test maddelerine verdikleri cevaplar arasındaki tutarlılık olarak da tanımlanabilen güvenirlik, test ile ölçülmek istenen özelliğin ne derece doğru ölçüldüğü ile ilgilidir. Bunun için çalışmada Cronbach-alfa güvenirlik katsayısı hesaplanmıştır. Bilindiği gibi bu katsayı, testten elde edilen puanlar arasındaki iç tutarlılığın bir ölçüsüdür ve eğitim çalışmalarında .70 ve üzeri değerler, testin güvenirliği için yeterli kabul edilmektedir (Büyüköztürk, 2011).

\section{Bulgular ve Yorumlar}

\section{Alt-Üst Grup Ortalamaları Farkına Dayalı Madde Analizinden Elde Edilen Bulgular}

Araştırmada test toplam puanlarına göre oluşturulan alt \%27 ile üst \%27'lik grupların madde ortalama puanları arasındaki farkın anlamlılı̆̆ı bağımsız gruplar için t-testi ile sınanmıştır. $\mathrm{Bu}$ süreçte elde edilen bulguların analizinde tüm maddelerin $\mathrm{t}$ değerlerinin anlamlı olduğu görülmüştür. Bu nedenle alt-üst grup ortalamaları farkına dayalı madde analizi sonucunda ölçekten herhangi bir madde çıkarılmamıştır. 
Çalışmada ölçekte yer alan maddelerin madde-toplam korelasyonları hesaplanmış ve elde edilen veriler Tablo 3 'te verilmiştir.

Tablo 3 Madde Analizi Sonuçlanı

\begin{tabular}{|c|c|c|c|}
\hline \multicolumn{2}{|c|}{ Maddeler } & \multirow{2}{*}{$\begin{array}{c}\begin{array}{c}\text { Madde Toplam } \\
\text { Korelasyonu }^{1}\end{array} \\
.503\end{array}$} & \multirow{2}{*}{$\begin{array}{c}\mathbf{t} \\
\left(\begin{array}{c}\text { Alt } \% \text { 27-Üst } \\
\mathbf{\% 2 7})^{\mathbf{2}}\end{array}\right. \\
-15.524^{* * *}\end{array}$} \\
\hline 1 & Geometrik bir problemin farklı vollarla cözülebilmesi hosuma gidivor & & \\
\hline 2 & Geometrinin önemli olduğunu düșünmüyorum. & .186 & $-4.915^{* * *}$ \\
\hline 3 & Geometriyi severim. & .664 & $-21.726^{* * *}$ \\
\hline 4 & Geometrik çizimler yapmayı sevmiyorum. & .150 & $-3.982^{* * *}$ \\
\hline 5 & Geometrinin ilköğretimde de ayrı bir ders olarak okutulmasını isterim. & .263 & $-7.345^{* * *}$ \\
\hline 6 & Geometri sınavlarından korkarım. & .466 & $-15.714^{* * *}$ \\
\hline 7 & Geometri herkes için gereklidir. & .454 & $-14.201^{* * *}$ \\
\hline 8 & Geometride 3 . boyutu görmede zorlanırım. & .297 & $-8.696^{* * *}$ \\
\hline 9 & Geometri sadece sınavlarda işime yarar. & .456 & $-13.677^{* * *}$ \\
\hline 10 & Geometriden nefret ederim. & .671 & $-24.035^{* * *}$ \\
\hline 11 & Verilen probleme uygun geometrik şekli çizebilirim. & .398 & $-11.228^{* * *}$ \\
\hline 12 & Geometrik ispatları yapamam. & .405 & $-11.857^{* * *}$ \\
\hline 13 & Geometri dünyayı anlamamıda etkilidir. & .427 & $-12.388^{* * *}$ \\
\hline 14 & $\begin{array}{l}\text { 9. Sınıfta bütün öğrencilere geometri dersi okutulmasını gereksiz } \\
\text { bulurum. }\end{array}$ & .452 & $-12.752^{* * *}$ \\
\hline 15 & Gördüğüm bir şekle ait geometrik çizimi yapabilirim. & .418 & $-10.851^{* * *}$ \\
\hline 16 & Geometri bilgileri gerçek yaşamdaki bilgilerle bağlantılı değildir. & .471 & $-13.249^{* * *}$ \\
\hline 17 & Geometri bilgilerimi günlük hayatta kullanabilirim. & .424 & $-12.680^{* * *}$ \\
\hline 18 & 3 boyutlu cisimlerin açık şekillerini kolaylıkla çizemem. & .264 & $-7.647^{* * *}$ \\
\hline 19 & Geometride kendimi başarılı görüyorum. & .551 & $-16.907^{* * *}$ \\
\hline 20 & Geometri anlamamı geliştiren oyunlar oynamaktan hoşlanmam. & .359 & $-10.047^{* * *}$ \\
\hline 21 & Boş zamanlarımda geometri problemleri çözmekten hoşlanırım. & .604 & $-19.163^{* * *}$ \\
\hline 22 & Geometrik ilişkileri görmede kendime güvenmiyorum. & .500 & $-15.768^{* * *}$ \\
\hline 23 & Bir sorunun farklı yollardan çözümünü yapabilirim. & .496 & $-13.611^{* * *}$ \\
\hline 24 & $\begin{array}{l}\text { Geometrik bir problemin çözümüne dair bütün bilgilere sahip olsam da } \\
\text { çözüme ulaşmakta zorlanırım. }\end{array}$ & .371 & $-10.087^{* * *}$ \\
\hline 25 & Daha fazla geometri öğrenmeye ihtiyaç duyuyorum. & .292 & $-7.298^{* * *}$ \\
\hline 26 & Geometride kullanılan formülleri çıkaramam. & .502 & $-14.686^{* * *}$ \\
\hline 27 & Geometri etrafımdaki nesneleri daha iyi algılamamda yardımcı olur. & .463 & $-13.308^{* * *}$ \\
\hline 28 & Geometride öğrendiğim konular arasında ilişki kuramam. & .477 & $-14.121^{* * *}$ \\
\hline 29 & $\begin{array}{l}\text { Geometri dersinin yalnız seçmeli ders olarak okutulması gerektiğini } \\
\text { düşünürüm. }\end{array}$ & .475 & $-14.513^{* * *}$ \\
\hline 30 & Geometri derslerinde kendimi rahat hissetmiyorum. & .551 & $-17.118^{* * *}$ \\
\hline 31 & Geometri ile ilgili çözülebilir bir problem oluşturabilirim. & .528 & $-15.687^{* * *}$ \\
\hline 32 & Geometri ile ilgili konularda tartışmalara katılmak hoşuma gitmez. & .514 & $-14.995^{* * *}$ \\
\hline 33 & Geometri dersinin haftalık ders saatlerinin artırılmasını isterim. & .545 & $-18.676^{* * *}$ \\
\hline 34 & Üniversite sınavında daha çok geometri sorusu çıkmasını istemem. & .391 & $-11.268^{* * *}$ \\
\hline 35 & $\begin{array}{l}\text { Zor bir geometri problemi olsa da sonunda çözüme ulaşabileceğime olan } \\
\text { inancım tamdır. }\end{array}$ & .544 & $-17.855^{* * *}$ \\
\hline 36 & $\begin{array}{l}\text { Doğada var olan geometri bana (salyangoz kabuğundaki altın oran vb.) } \\
\text { ilgi çekici gelmez. }\end{array}$ & .353 & $-8.179^{* * *}$ \\
\hline 37 & Ödüllü geometri sorularını (olimpiyat vb.) çözmek için uğraşırım. & .459 & $-13.373^{* * *}$ \\
\hline 38 & $\begin{array}{l}\text { Günlük hayatla ilişkili örnekler görmek geometri öğrenme isteğimi } \\
\text { artırmaz. }\end{array}$ & .525 & $-14.622^{* * *}$ \\
\hline 39 & Geometrinin tarihsel gelişimini öğrenmekten zevk alırım. & .374 & $-10.546^{* * *}$ \\
\hline 40 & Geometri bilgilerimi diğer derslerde kullanamam. & .466 & $-13.116^{* * *}$ \\
\hline
\end{tabular}


Analiz sürecinde $2,4,5,8,11,18,20,24,25,34,36$ ve 39 nolu maddeler, madde toplam korelasyonlarının .40'dan küçük olması nedeniyle ölçekten çıkarılmıştır. Sözü edilen maddeler dışındaki maddelerin tümü için madde-toplam korelasyonlarının .405-.671 arasında değiştiği ve $t$ değerlerinin anlamlı olduğu görülmektedir (Tablo 3). Bu veriler ölçekteki maddelerin kişileri ayırt etme özelliğine sahip olduğunu göstermektedir.

\section{Açımlayıcı Faktör Analizinden Elde Edilen Bulgular}

Geometri Tutum Ölçeği'nin faktör yapısı temel bileşenler analiziyle (Principle Compenent Analysis (PCA) değerlendirilmiştir. Öncelikle verinin analiz için uygunluğunu sınamak amaciyla Kaiser-Meyer-Olkin (KMO) değeri hesaplanarak 0.942 değeri tespit edilmiş ve verinin faktör analizi için uygun olduğu görülmüştür. Bu aşamadan sonra, aralarında yüksek korelasyon bulunan değişkenlerin bir araya getirilmesi amacıyla faktör analizi yapılmıştır. Burada amaç değişken sayısını azaltarak değişkenleri sınıflandırmaktır. Bunun için, değişkenlerin ortak varyansına bakılmıştır. Hair vd. (1998, alıntı: Kalaycı, 2005), ortak varyansın, bir değişkenin analizde yer alan değişkenlerle paylaştığ 1 varyans miktarı olduğunu belirtmektedir. Ölçekte yer alan maddelerin ortak faktör varyans değerlerinin .356 ile .644 arasında değiştiği belirlenmiştir. $\mathrm{Bu}$ sonuçlara göre, maddelerin ortak faktör varyanslarının yüksek değerde olduğu söylenebilir. Bu nedenle bu aşamada ölçekten herhangi bir madde çıkarılmamıştır.

Ölçekte yer alan maddelere yapılan temel bileşenler analizi sonucunda analize alınan 28 maddenin özdeğeri 1'den büyük olan beş faktör altında toplandığ görülmüştür. Bu faktörlerin özdeğerleri 8.56, 1.81, 1.41, 1.15 ve 1.02 şeklindedir. $\mathrm{Bu} 5$ faktör toplam varyansın \%49.785'ini açıklamıştır. Özdeğer grafiğgi (scree plot) incelendiğinde dört ya da beş faktörlü çözümlemenin uygun olduğu görülmüştür. Faktör sayısını belirlemek için paralel analiz yapılmış ve analiz sonucu dört faktörlü çözümlemenin uygun olduğuna işaret etmiştir. Ayrıca varimax rotasyonu kullanılarak ölçek maddeleri beş faktöre zorlandığında son faktörün faktör analizi sayıltısını (bir faktörün en yüksek madde faktör yükünün .50'nin altında olmaması) karşılamadığı ve bazı maddelerin birden fazla faktörde yük aldığı görülmüştür. Burada iki faktördeki yük farkı 0.1 ve altında olan 3,37, 6 ve 10. maddeler ölçekten çıkarılarak varimax rotasyonuyla ikinci kez faktör analizi yapılmıştır. $\mathrm{Bu}$ analiz sonucunda ölçekte yer alan maddelerin faktör ortak varyans ve faktör yük değerleri Tablo 4'te sunulmuştur. Bu işlem ile özdeğerler için birikimli varyansın \%47.03 olduğu belirlenmiştir yani bu dört faktör ile ölçülmek istenen tutumların \%47.03’ü açıklanmaktadır. Scherer, Wiebe, Luther \& Adams, 
1988, alıntı: Tavşancıl, 2002), varyans oranının \%40-\%60 arasında değişmesinin sosyal bilimler alanında yürütülen çalışmalarda ölçeğin faktör yapısının güçlü olduğunu işaret ettiğini belirtmektedir. $\mathrm{O}$ halde hesaplanılan toplam varyans değerinin belirtilen aralıkta kalması nedeniyle faktör yapısı güçlü bir ölçek oluştuğunu söyleyebiliriz.

Tablo 4 Nihai Ölçekte Yer Alan Maddelerin Ortak Varyans ve Faktör Yük Değerleri

\begin{tabular}{|c|c|c|c|c|c|c|}
\hline \multirow[b]{2}{*}{ Madde no } & \multirow{2}{*}{$\begin{array}{c}\text { Faktör } \\
\text { Ortak } \\
\text { Varyansı } \\
\end{array}$} & \multirow{2}{*}{$\begin{array}{l}\text { Faktör-1 } \\
\text { yük değeri }\end{array}$} & \multicolumn{4}{|c|}{ Döndürme Sonrası Yük Değeri } \\
\hline & & & Faktör-1 & Faktör-2 & Faktör-3 & Faktör-4 \\
\hline Madde 35 & .574 & .612 & .709 & & & \\
\hline Madde 19 & .560 & .614 & .701 & & & \\
\hline Madde 23 & .489 & .566 & .634 & & & \\
\hline Madde 21 & .489 & .649 & .573 & & & \\
\hline Madde 1 & .421 & .576 & .568 & & & \\
\hline Madde 31 & .400 & .578 & .549 & & & \\
\hline Madde 33 & .475 & .580 & .514 & & & .404 \\
\hline Madde 28 & .474 & .543 & & .619 & & \\
\hline Madde 32 & .452 & .574 & & .603 & & \\
\hline Madde 26 & .435 & .553 & & .574 & & \\
\hline Madde 40 & .475 & .519 & & .536 & & \\
\hline Madde 22 & .472 & .543 & & .524 & & \\
\hline Madde 12 & .373 & .439 & & .513 & & \\
\hline Madde 38 & .479 & .555 & & .509 & .383 & \\
\hline Madde 30 & .441 & .613 & .335 & .438 & & \\
\hline Madde 17 & .554 & .502 & & & .698 & \\
\hline Madde 27 & .496 & .524 & & & .664 & \\
\hline Madde 13 & .422 & .479 & & & .604 & \\
\hline Madde 9 & .475 & .512 & & .326 & .581 & \\
\hline Madde 15 & .354 & .428 & & & .524 & \\
\hline Madde 7 & .428 & .505 & & & .515 & \\
\hline Madde 16 & .475 & .529 & & & .471 & .348 \\
\hline Madde 14 & .616 & .479 & & & & .743 \\
\hline Madde 29 & .589 & .541 & & & & .669 \\
\hline Açıklanan Varyans & & & $\% 14.69$ & $\% 12.48$ & $\% 12.31$ & $\% 7.54$ \\
\hline
\end{tabular}

Açımlayıcı faktör analizi sonucunda 7 maddenin $(35,19,23,21,1,31,33$ nolu maddeler) birinci faktör altında, 8 maddenin $(28,32,26,40,22,12,38,30$ nolu maddeler) ikinci faktör altında, 7 maddenin $(17,27,13,9$, 15, 7, 16 nolu maddeler) üçüncü faktör altında ve 2 maddenin $(14,29$ nolu maddeler) dördüncü faktör altında toplandığı belirlenmiştir. Ardından faktörlerde yer alan maddeler incelenerek anlamca uygun ilişki bulunmadığ1 durumlarda, ilgili madde faktör yükünün daha düşük olduğu diğer faktöre kaydırılmıştır. Bu işlem sonucu 30. madde birinci faktöre; 38. madde üçüncü faktöre ve son olarak 33. madde 
dördüncü faktöre kaydırılmıştır. Sonuç olarak birinci faktörün kendini yeterli görme ve geometriden hoşlanma (1, 19, 21, 23, 30, 31 ve 35. maddeler), ikinci faktörün geometrik kavramları ilişkilendirme (12, 22, 26, 28, 32 ve 40. maddeler), üçüncü faktörün geometri gerçek yaşam ilişkisi $(7,9,13,15,16,17,27$ ve 38. maddeler) ve dördüncü faktörün geometri dersinin ögretim programındaki yeri (14, 29 ve 33) adlandırılmasının uygun olduğu düşünülmüşsür.

\section{Doğrulayıcı Faktör Analizinden Elde Edilen Bulgular}

Birinci düzey (first order) doğrulayıcı faktör analizi sonucunda dört faktörlü model ile verinin iyi uyum gösterdiği görülmüştür $\left(\chi^{2}(246, N=639)=640.50, p<.001, \operatorname{RMSEA}=.05\right.$, $\mathrm{CFI}=.97)$ ve $\chi^{2} /$ sd değeri 2.60 'dır ve elde edilen değerler modelin kabul edilebilir bir uyum iyiliği değerine sahip olduğunu göstermektedir (Byrne, 1998). Ölçek maddelerin açıkladıkları varyans değerleri ve t değerleri Tablo 5'de, analiz sonuçları Şekil 1'de sunulmuştur.

Tablo 5 DFA Sonucunda Maddelerin Açıkladıkları Varyans Değerleri ve t Değerleri

\begin{tabular}{|c|c|c|c|}
\hline Ölçek Maddeleri & $\mathbf{R}^{2}$ & Lamda-x & $\mathbf{t}$ \\
\hline Madde 1 & .33 & .57 & $16.45^{* * *}$ \\
\hline Madde 7 & .28 & .65 & $16.30 * * *$ \\
\hline Madde 9 & .35 & .67 & $15.70 * * *$ \\
\hline Madde 12 & .19 & .59 & $16.95 * * *$ \\
\hline Madde 13 & .29 & .60 & $16.21 * * *$ \\
\hline Madde 14 & .27 & .58 & $15.71 * * *$ \\
\hline Madde 15 & .20 & .65 & $16.87 * * *$ \\
\hline Madde 16 & .34 & .43 & $15.84 * * *$ \\
\hline Madde 17 & .35 & .58 & $15.69 * * *$ \\
\hline Madde 19 & .42 & .59 & $15.76^{* * *}$ \\
\hline Madde 21 & .45 & .59 & $15.55^{* * *}$ \\
\hline Madde 22 & .34 & .59 & $15.79 * * *$ \\
\hline Madde 23 & .35 & .51 & $16.33 * * *$ \\
\hline Madde 26 & .35 & .53 & $15.68 * * *$ \\
\hline Madde 27 & .37 & .59 & $15.46^{* * *}$ \\
\hline Madde 28 & .35 & .54 & $15.65 * * *$ \\
\hline Madde 29 & .36 & .45 & $14.49 * * *$ \\
\hline Madde 30 & .36 & .58 & $16.26^{* * *}$ \\
\hline Madde 31 & .33 & .59 & $16.42 * * *$ \\
\hline Madde 32 & .35 & .61 & $15.69 * * *$ \\
\hline Madde 33 & .40 & .55 & $13.64 * * *$ \\
\hline Madde 35 & .43 & .52 & $15.71 * * *$ \\
\hline Madde 40 & .26 & .64 & $16.45 * * *$ \\
\hline
\end{tabular}


Doğrulayıcı faktör analizi sonucunda gizil değişkenleri temsil eden maddelerin faktör yükleri incelendiğinde birinci faktörü (kendini yeterli görme ve geometriden hoşlanma alt boyutu) temsil eden maddelerin faktör yüklerinin .57-.67; ikinci faktörü (geometrik kavramları ilişkilendirme alt boyutu) temsil eden maddelerin faktör yüklerinin .43-.59; üçüncü faktörü (geometri gerçek yaşam ilişkisi) temsil eden maddelerin faktör yüklerinin .45.61; dördüncü faktörü (geometri dersinin öğretim programındaki yeri) temsil eden maddelerin faktör yüklerinin .52-.64 arasında değiştiği görülmüştür.

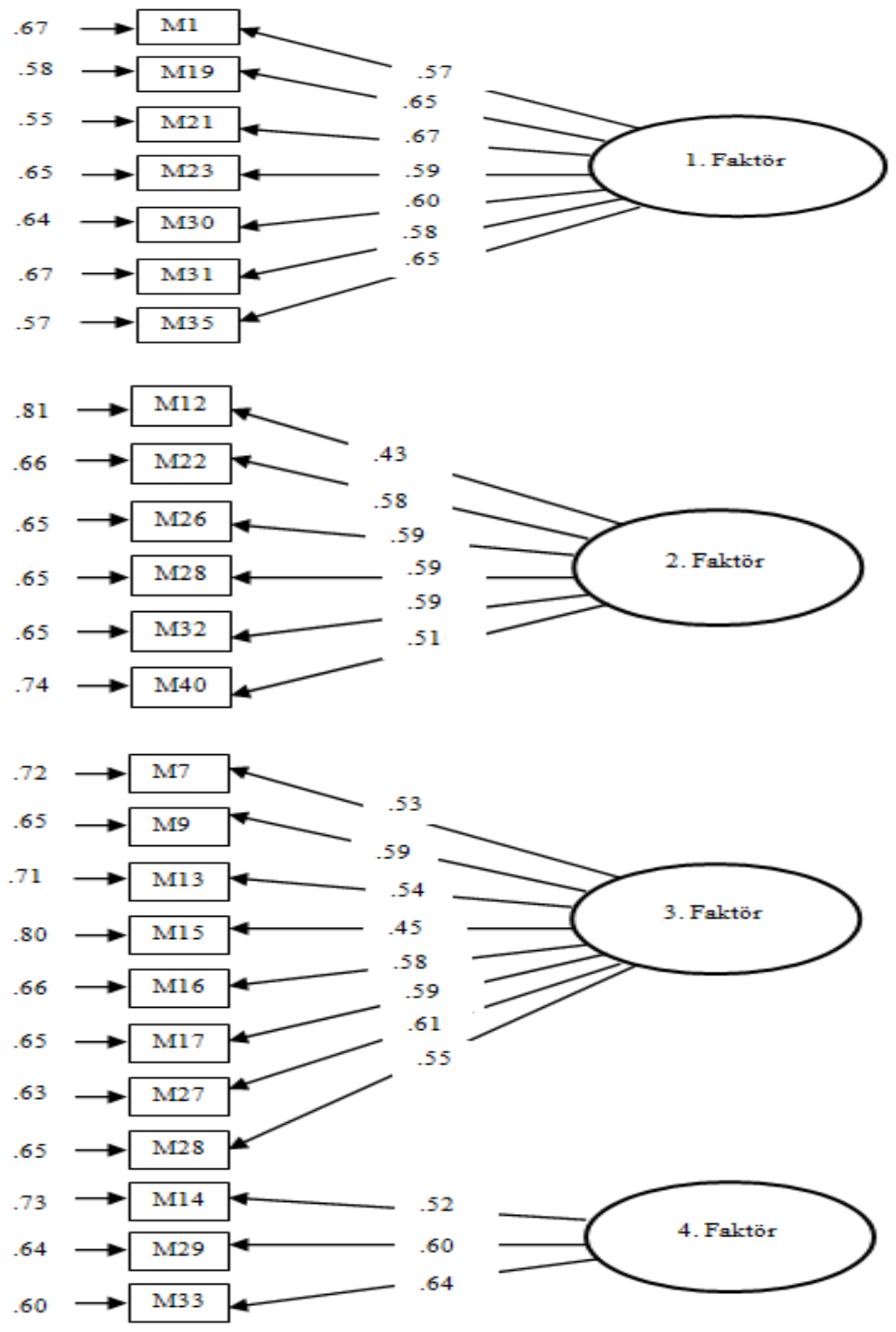

Şekil 1 Doğrulayıcı faktör analizi sonuçları

Gizil değişkenler arası yapısal korelasyonlar incelendiğinde, değişkenler arası yüksek bir ilişkinin olduğu görülmüştür (Bkz. Tablo 6). 
Tablo 6 Ölçek Alt Faktörleri Arasındaki Korelasyonlar

\begin{tabular}{ccccc}
\hline Faktörler & $\mathbf{1}$ & $\mathbf{2}$ & $\mathbf{3}$ & $\mathbf{4}$ \\
\hline $\mathbf{1}$ & 1 & & & \\
$\mathbf{2}$ & $.85^{* *}$ & 1 & & \\
$\mathbf{3}$ & $.66^{* *}$ & $.67^{* *}$ & 1 & \\
$\mathbf{4}$ & $.82^{* *}$ & $.72^{* *}$ & $.69^{* *}$ & 1 \\
\hline$* * * \mathrm{p}<.001$ & & & &
\end{tabular}

Yapılan ikinci düzey DFA analizleri sonucunda dört faktörün temsil edildiği geometri tutum alt boyutlarından oluşan ikinci düzey model ile verinin iyi uyum gösterdiği görülmüştür $\left(\chi^{2}(248, N=639)=638.56, p<.001, \mathrm{RMSEA}=.05, \mathrm{CFI}=.97\right)$ ve $\chi^{2} / \mathrm{sd}$ değeri 2.57 'dir ve elde edilen değerler modelin kabul edilebilir bir uyum iyiliği değerine sahip olduğunu göstermektedir. İkinci düzey modeldeki tüm faktörlerin standartlaştırılmış yükleri, birinci faktör (kendini yeterli görme ve geometriden hoşlanma alt boyutu) için .94; ikinci faktör (geometrik kavramları ilişkilendirme alt boyutu) için .89; üçüncü faktör (geometri gerçek yaşam ilişkisi) için .73; dördüncü faktör (geometri dersinin öğretim programındaki yeri) için .86 olarak hesaplanmıştır. Birinci düzey ve ikinci düzey DFA sonuçları karşılaştırıldığında Geometri Tutum Ölçeğinin alt boyutlarını oluşturan maddelerin alt boyutları temsil edici gücünün kabul edilebilir düzeyde olduğu ve bu alt boyutların tek boyutlu geometri tutum ölçeği gizil değişkenini temsil ettiği görülmüştür.

\section{Güvenirlik ile İlgili Bulgular}

Geometri Tutum Ölçeği’nin iç tutarlığg, madde analizine bağlı olarak hesaplanan Cronbach Alpha katsayısı ile incelenmiştir. Alt ölçeklerin iç tutarlık katsayıları, birinci faktör (kendini yeterli görme ve geometriden hoşlanma) için .810; ikinci faktör (geometrik kavramları ilişkilendirme) için .717; üçüncü faktör (geometri gerçek yaşam ilişkisi) için .780; dördüncü faktör (geometri dersinin öğretim programındaki yeri) için .614 olarak hesaplanmıştır. Diğer taraftan son faktör için hesaplanan değerin düşük olmasının nedeni bu faktör altında yer alan madde sayısının az olması olabilir. Buradan anlaşılacağı üzere ölçeğin ilk üç faktörü için hesaplanan değer .70'in üzerinde olduğundan bu faktörler güvenilir olarak nitelendirilebilir. Dördüncü faktör için hesaplanan değer yeni bir ölçek için ön görülen .60'1n üzerindedir. Zira 0.614 değerinin yeni geliştirilen ölçekler için 60 değerinden büyük olduğundan bu faktör de güvenilir olarak nitelendirilebilir (Child, 1970; aktaran TokayArgan, Argan \& Kurulgan, 2008). Ölçeğin toplam Cronbach Alfa katsayısı ise .895 olarak bulunmuştur. Hesaplanan bu değer $0.80 \leq \alpha \leq 1.00$ aralığında olduğundan ölçek yükssek derecede güvenilirdir (Kalaycı, 2005). Yani elde edilen değerler, araştırma örnekleminde 
Geometri Tutum Ölçeği’ne ait alt boyutların kabul edilebilir iç tutarlığa sahip olduğunu göstermektedir.

\section{Sonuç ve Tartışma}

Öğrencilerin geometride başarısız olmaları salt geometriye has özelliklerden kaynaklanmamaktadır. Zira geometride bir çok şekil ve cisim farklı yönlerden ele alınmakta, ve bunlar ile ilgili birçok matematiksel hesaplama gerekmektedir (Çelebi-Akkaya, 2006). Başarı ile tutumun yakından ilişkili olduğu göz önünde bulundurulduğunda öğrencilerin söz konusu derse karşı tutumlarının belirlenmesi ve elde edilen sonuçlara göre gereken önlemlerin alınması gerekmektedir. Bu çalışma kapsamında da öğrencilerin geometriye karşı tutumlarını belirlemeye yönelik geçerli ve güvenilir bir ölçek geliştirilmiştir. Çalışma Ordu ilinde ortaöğretim kurumlarında öğrenim gören 639 öğrenci ile yürütülmüştür. 40 maddeden oluşan taslak ölçek yapılan analizler sonucu 24 maddeye indirilmiştir. Bu nihai ölçek 4 faktörden oluşmaktadır. Faktörlerin açıkladığı varyanslar sırasıyla \%14.69, \%12.48, \%12.31 ve \%7.54; toplam açıklanan varyans \%47.03'tür. Ölçeğin alt boyutlarına ilişkin Cronbach Alpha katsayılarının yüksek olması (kendini yeterli görme ve geometriden hoşlanma alt boyutu $=.810$; geometrik kavramları ilişkilendirme alt boyutu=.717; geometri gerçek yaşam ilişkisi=.780; geometri dersinin öğretim programındaki yeri= .614 ), alt boyutlarda yer alan maddelerin birbiriyle tutarlı olduğunu göstermektedir. AFA ve DFA sonuçları da ölçeğin geçerliliğini onaylamıştır. Bu durum geliştirilen ölçeğin öğretim programı değişikliğinin beraberinde getirdiği yeni amaç, beceri ve yaklaşımları hesaba katması sebebiyle yeni öğretim programının uygulamalarında öğrencilerin geometriye karşı tutumlarını belirlemede kullanılmak üzere uygun nitelikler taşıdı̆̆ını göstermektedir.

Öğrencilerin duyuşsal gelişimi geometri ile ilgili kavram ve becerilerin gelişmesi sürecinde göz önünde bulundurulmalıdır (MEB, 2010). Araştırmada geliştirilen tutum ölçeğinin birinci faktöründe yer alan maddelerin bir kısmı öğrencilerin geometri ile ilgili duyuşsal özellikleri ile ilgilidir. O halde öğrencilerin süreç içerisinde duyuşsal gelişimi göz önünde bulundurulurken geliştirilen ölçeğin bu noktada yardımcı olacağı düşünülmektedir.

Geometrinin sadece kural, sembol, şekil ve işlemlerden oluştuğunu söyleyemeyiz, keza geometrinin içinde anlam bütünlüğü olan düzenler ve ilişkiler ağı olduğu gibi geometri ile diğer disiplinler ve yaşam arasında da ilişkiler bulunmaktadır (MEB, 2010). Araştırmada geliştirilen tutum ölçeğinin ikinci faktörü geometrik kavramların birbiriyle ilişkisi, üçüncü faktörü ise geometrinin gerçek yaşam ile ilişkisi ile ilgili tutumları işaret etmektedir. 
Dolayısıyla öğretim programında önemle üzerinde durulan ilişkilendirme becerisi ile ilgili tutumlar araştırmamızda geliştirilen tutum ölçeği aracılığı ile belirlenebilecektir. Ayrıca uygulamadaki 2010 geometri öğretim programı ile öğretmenlerin öğrencilerinin tutumlarını belirlemede kullanabilecekleri örnek tutum ölçeği-daha önce uygulamaya konan matematik programında örnek matematik tutum ölçeği verilmesine rağmen- öğretim programının ekler kısmında verilmemiştir. $\mathrm{Bu}$ açıdan araştırmanın bu alandaki boşluğu doldurduğu düşünülmektedir. Ayrıca, bu araştırmanın bulguları farklı derslerin duyuşsal alana etkilerinin inceleneceği araştırmalar kapsamında geliştirilecek tutum ölçeklerine 1şık tutabilir.

\section{Öneriler}

Araştırma kapsamında geliştirilen ölçeğin, öğretim programı değişikliğinin beraberinde getirdiği yeni amaç, beceri ve yaklaşımları hesaba katması sebebiyle yeni öğretim programının uygulamalarında öğrencilerin geometriye karşı tutumlarını belirlemek için kullanılması önerilmektedir. Ayrıca bu ölçek kullanılarak öğrencilerin geometriye karşı tutumlarının çeşitli değişkenler açısından (cinsiyet, sınıf, başarı düzeyi, coğrafi bölge vb.) incelenmesi önerilmektedir. Diğer taraftan yukarıda belirtildiği gibi dersin amaçları arasında olmasına rağmen 2010 Geometri Dersi Öğretim Programında örnek tutum ölçeğine yer verilmemesi nedeniyle çalışmamızda geliştirilen ölçeğin gerekli durumlarda öğretmenler tarafından kullanılması yararlı olacaktır.

\section{Kaynakça}

Aşkar, P. (1986). Matematik dersine yönelik tutumu ölçen likert-tipi bir ölçeğin geliştirilmesi. Eğitim ve Bilim, 11 (62), 31-36.

Barutçu-Akyar, K. (2010). Öklid geometrisi öğretiminde dinamik geometri yazılımları kullanımının 11. sınıf ögrencilerinin geometriye yönelik tutumlarına ve akademik başarılarına etkileri. Yayınlanmamış yüksek lisans tezi. Dokuz Eylül Üniversitesi, İzmir.

Baykul, Y. (1990). Illkokul beşinci sınıftan lise ve dengi okulların son sınıflarına kadar matematik ve fen derslerine karşı tutumda görülen değişmeler ve öğrenci seçme sınavındaki başarı ile ilişkili olduğu düşünülen bazı faktörler. Ankara: ÖSYM Yayınları.

Baykul, Y. (2002). İlköğretimde matematik öğretimi. Ankara: Pegem Yayıncılık. 
Bayram, S. (2004). The effect of instruction with concrete models on eighth grade students' geometry achievement and attitudes toward geometry. Yayınlanmamış yüksek lisans tezi. ODTÜ, Ankara.

Bindak, R. (2004). Geometri tutum ölçeği güvenirlik geçerlik çalışması ve bir uygulama. Yayınlanmamış doktora tezi. Dicle Üniversitesi, Diyarbakır.

Bulut, S., Ekici, C., İşeri, A. İ., \& Helvacı, E. (2002). Geometriye yönelik tutum ölçeği. Eğitim ve Bilim, 27(125), 3-7.

Büyüköztürk, Ş. (2011). Sosyal Bilimler için Veri Analizi El Kitabı, 13. baskı, Ankara: Pegem A Yayıncilik.

Byrne B. M. (1998). Structural equation modeling with LISREL, PRELIS AND SIMLIS: Basic concepts, applications and programming. Mahwah, NJ: Lawrence Erlbaum Associates.

Byrne, B. M. (2001). Structural equation modeling with AMOS, EQS, and LISREL: Comparative approaches to testing for the factorial validity of a measuring instrument. International Journal of Testing, 1, 55-86.

Child, D. (1970). The essentials of factor analysis. London: Holt, Rhinehart \& Winston.

Çelebi-Akkaya, S. (2006). Van Hiele düzeylerine göre hazırlanan etkinliklerin ilköğretim 6. sınıf öğrencilerinin tutumuna ve başarısına etkisi. Yayınlanmamış yüksek lisans tezi. Abant İzzet Baysal Üniversitesi, Bolu.

Duatepe, A., \& Çilesiz, Ş. (1999). Matematik tutum ölçeği geliştirilmesi. Hacettepe Üniversitesi Ë̆itim Fakültesi Dergisi, 16-17, 45-52.

Duatepe, A., \& Ubuz, B. (2007). The development of a geometry attitude scale. Academic Exchange Quarterly, 11 (2), 3679-3685.

Erol, E. (1989). Prevalence and correlates of math anxiety in Turkish high school students. Yayınlanmamış yüksek lisans tezi. Boğaziçi Üniversitesi, İstanbul.

Fraenkel, J.R., \& Wallen, N. E. (2006). How to design and evaluate research in education (6th ed.). New York: McGraw-Hill

Güven, Y. (2006). Farklı geometrik çizim yöntemleri kullanımının öğrencilerin başarı, tutum ve Van Hiele geometri anlama düzeylerine etkisi. Yayınlanmamış yüksek lisans tezi. KTÜ, Trabzon.

Hair J. F., Anderson R. E., Tahtam R. L., \& Black, W. C. (1998). Multivariate data analysis $\left(5^{\text {th }}\right.$ Edition). New Jersey: Prentice-Hall. 
Hammouri, H. A. M. (2004). Attitudinal and motivational variables related to mathematics achievements from Third International and Science Study (TIMSS). Educational Research, 46(3), 241-257.

Işık, E., \& Çağdaşer, B. T. (2009). Yapısalcı yaklaşımla cebir öğretiminin 6. sınıf öğrencilerinin matematiğe yönelik tutumlarına etkisi. Kastamonu Eğitim Dergisi, 17(3), 941-954.

Kalaycı, Ș. (Ed.). (2005). SPSS uygulamalı çok değişkenli istatistik teknikleri. Ankara: Asil Yayın Dağıtım.

Ma, X., \& Xu, J. (2004). Determining causal ordering between attitude toward mathematics and achievement in mathematics. American Journal of Education, 110 (3), 256-280.

Mathematics. Reston, VA: Author.

MEB (1992). Ortä̈ğretim matematik dersi 9-11. sinıflar ögretim programı, Talim ve Terbiye Kurulu Başkanlığı, Ankara.

MEB (2004). Yeni matematik dersi programı ve kllavuzu. Ankara: MEB Talim ve Terbiye Kurulu Başkanlığı.

MEB (2005a). Matematik dersi ögretim programı ve kılavuzu. Ankara: MEB Talim ve Terbiye Kurulu Başkanlığı.

MEB (2005b). İlköğretim okulu matematik dersi (1-5.sınıflar) öğretim programı. Ankara: MEB Talim ve Terbiye Kurulu Başkanlığı.

MEB (2010). Ortä̈ğretim geometri dersi 9-10. sinıflar öğretim programı. Ankara: MEB Talim ve Terbiye Kurulu Başkanlığı.

Mullis, I. V. S., Martin, M. O., Gonzalez, E. J., Gregory, K. D., Garden, R. A., \& O’Connor, K. M. (2000). TIMSS 1999 International Mathematics Report: Findings from IEA's repeat of the Third International Mathematics and Science Study at the Eighth Grade. Chestnut Hill, MA: Boston College.

National Council of Teachers of Mathematics. (2000). Principles and Standards For School

Nazlıçiçek, N. \& Erktin, E. (2002). İlköğretim matematik öğretmenleri için kısaltılmış matematik tutum ölçeği. V. Ulusal Fen Bilimleri ve Matematik Eğitimi Kongresi Bildiriler Kitabı, 860-865.

Ocak, G., \& Dönmez, S. (2010). İlköğretim 4. ve 5. sınıf öğrencilerinin matematik etkinliklerine yönelik tutum ölçeği geliştirme. Kuramsal Eğitimbilim, 3(2), 69-82.

Övez, M. G. (2007). Ortä̈ğretim 9. sinıf matematik ögrretiminde proje tabanlı ögretimin öğrenci başarısına etkisi. Yayınlanmamış yüksek lisans tezi. Balıkesir Üniversitesi, Balıkesir. 
Özdoğan, E. (2008). İşbirlikli öğrenme yönteminin ilköğretim 4. sınıf matematik ögrretiminde ögrrenci tutum ve başarısına etkisi: bilgisayar destekli işbirlikli öğrenme ve küme destekli bireyselleştirme tekniği. Yayınlanmamış yüksek lisans tezi. Ege Üniversitesi, İzmir.

Papanastasiou, C. (2000). Effects of attitudes and beliefs on mathematics achievement. Studies in Educational Evaluation, 26, 27-42.

Papanastasiou, E. (2002) Factors that differentiate mathematics students in Cyprus, Hong Kong, and USA. Educational Research and Evaluation, 8(1), 129-146.

Peker, M., \& Mirasyedioğlu, Ş. (2003). Lise 2. sınıf öğrencilerinin matematik dersine yönelik tutumları ve başarıları arasındaki ilişki. Pamukkale Üniversitesi Eğitim Fakültesi Dergisi, 2 (14), 157-166.

Savaş E., Taş, S., \& Duru, A. (2010). Factors affecting students' achievement in mathematics. Inonu University Journal of the Faculty of Education. 11(1), 113-132.

Scherer, R. F., Wiebe, F. A., Luther, D. C., \& Adams, J. S. (1988). Dimensionality of coping: Factor stability using the ways of coping questionnaire. Psychological Reports, 62(3), 763-770.

Sulak, S. A. (2002). Matematik dersinde bilgisayar destekli öğretimin öğrenci başarl ve tutumlarına etkisi. Yayınlanmamış yüksek lisans tezi. Selçuk Üniversitesi, Konya.

Tavşancıl, E. (2002). Tutumların Ölçülmesi ve SPSS ile Veri Analizi. Ankara: Nobel Yayıncılık.

Tavşancıl, E. (2005). Tutumların ölçülmesi ve SPSS ile veri analizi. Ankara: Nobel Yayın Dağıtım.

Tezbaşaran, A. (1997). Likert tipi ölçek geliştirme kılavuzu. Ankara: Türk Psikologlar Derneği Yayınları.

Tokay-Argan, M., Argan, M., \& Kurulgan, M. (2008). Kitaplara ilişkin biçimsel özelliklerin okuyucu tutumları üzerine etkisi. Bilgi Dünyası, 9 (1), 179-208.

Tutak, T. (2008). Somut nesneler ve dinamik geometri yazılımı kullanımının ögrencilerin bilişsel öğrenmelerine, tutumlarına ve Van Hiele geometri anlama düzeylerine etkisi. Yayınlanmamış doktora tezi. KTÜ. Trabzon. 
Ubuz, B., \& Üstün, I. (2003). Figural and conceptual aspects in identifying polygons. Proceedings of the 27th International Conference for the Psychology of Mathematics Education, USA, 1, 328.

Ural, A. (2007). İşbirlikli öğrenmenin matematikteki akademik başarıya, kalıcılı̆̆a, matematik özyeterlilik algısına ve matematiğe karşı tutuma etkisi. Yayınlanmamış doktora tezi. Gazi Üniversitesi, Ankara.

Üstün, I. (2003). Developing the understanding of geometry through a computer-based learning environment. Yayınlanmamış yüksek lisans tezi. ODTÜ, Ankara.

Üzel, D. (2007). Gerçekçi Matematik Ĕ̆itimi (RME) destekli ĕgitimin ilköğretim 7. sınıf matematik ögretiminde öğrenci başarısına etkisi. Yayınlanmamış doktora tezi. Balıkesir Üniversitesi, Balıkesir.

Webster, B. J., \& Fisher, D. L. (2000). Accounting for variation in science and mathematics achievements: A multi level analysis of Australian data Third International Mathematics and Science Study (TIMSS). School Effectiveness and School Improvements, 11(3), 339-360.

Wilkins, J. L. M., \& Ma, X. (2003). Modeling change in student attitude toward and beliefs about mathematics, The Journal of Educational Research, 97(1), 52-63.

Yıldız, S. (2006). Üniversite sınavına hazırlanan dersane öğrencilerinin matematik dersine karşı olan tutumları. Yayınlanmamış yüksek lisans tezi. Hacettepe Üniversitesi, Ankara.

Yıldız, S. \& Turanlı, N. (2010). Öğrenci seçme sınavına hazırlanan öğrencilerin matematik dersine yönelik tutumlarının belirlenmesi, Selçuk Üniversitesi Ahmet Keleşoğlu Ĕğitim Fakültesi Dergisi, 30, 361-377. 